\title{
Football Clubs as Mediators in Sponsor-stakeholder Relations
}

\author{
Junghagen, Sven
}

Document Version

Final published version

Published in:

Sport, Business and Management

DOI:

10.1108/SBM-02-2017-0007

Publication date:

2018

\section{License}

$\mathrm{CC} B Y$

Citation for published version (APA):

Junghagen, S. (2018). Football Clubs as Mediators in Sponsor-stakeholder Relations. Sport, Business and Management, 8(4), 335-353. https://doi.org/10.1108/SBM-02-2017-0007

Link to publication in CBS Research Portal

\section{General rights}

Copyright and moral rights for the publications made accessible in the public portal are retained by the authors and/or other copyright owners and it is a condition of accessing publications that users recognise and abide by the legal requirements associated with these rights.

Take down policy

If you believe that this document breaches copyright please contact us (research.lib@cbs.dk) providing details, and we will remove access to the work immediately and investigate your claim. 


\section{e emeraldinsight}

\section{Sport, Business and Management: An International Journal}

Football clubs as mediators in sponsor-stakeholder relations

Sven Junghagen,

\section{Article information:}

To cite this document:

Sven Junghagen, (2018) "Football clubs as mediators in sponsor-stakeholder relations", Sport, Business and Management: An International Journal, Vol. 8 Issue: 4, pp.335-353, https://

doi.org/10.1108/SBM-02-2017-0007

Permanent link to this document:

https://doi.org/10.1108/SBM-02-2017-0007

Downloaded on: 24 J anuary 2019, At: 00:51 (PT)

References: this document contains references to 77 other documents.

The fulltext of this document has been downloaded 699 times since 2018*

\section{Users who downloaded this article also downloaded:}

(2016),"Sport-related branded entertainment: the Red Bull phenomenon", Sport, Business and Management: An International Journal, Vol. 6 Iss 5 pp. 520-541 <a href="https://doi.org/10.1108/ SBM-06-2016-0023">https://doi.org/10.1108/SBM-06-2016-0023</a>

(2017),"Financial fair play and competitive balance in the Premier League", Sport, Business and Management: An International Journal, Vol. 7 Iss 2 pp. 175-196 <a href="https://doi.org/10.1108/ SBM-10-2016-0058">https://doi.org/10.1108/SBM-10-2016-0058</a>

Access to this document was granted through an Emerald subscription provided by All users group

\section{For Authors}

If you would like to write for this, or any other Emerald publication, then please use our Emerald for Authors service information about how to choose which publication to write for and submission guidelines are available for all. Please visit www. emeraldinsight.com/ authors for more information.

\section{About Emerald www.emeraldinsight.com}

Emerald is a global publisher linking research and practice to the benefit of society. The company manages a portfolio of more than 290 journals and over 2,350 books and book series volumes, as well as providing an extensive range of online products and additional customer resources and services.

Emerald is both COUNTER 4 and TRANSFER compliant. The organization is a partner of the Committee on Publication Ethics (COPE) and also works with Portico and the LOCKSS initiative for digital archive preservation.

*Related content and download information correct at time of download. 


\title{
Football clubs as mediators in sponsor-stakeholder relations
}

\author{
Sven Junghagen \\ Copenhagen Business School, Frederiksberg, Denmark
}

\begin{abstract}
Purpose - Far from all, football clubs can provide the same level of exposure effects as global football brands, even on local level, and many of these clubs also operate in a context of commercial immaturity. The purpose of this paper is to show what value a football club can provide for sponsors in a context of commercial immaturity with limited expected exposure effects.

Design/methodology/approach - The study is based on a case study approach, taking its point of departure in two sponsor brand management paradigms, the projective and relational paradigm. The case of Malmö FF in the Swedish top tier league and the club's official partners has been chosen to exemplify the commercially immature context.

Findings - The study has shown that the most important value the club can provide for sponsors is to act as a mediator in sponsor-stakeholder relations. Exposure effects are subordinate to the relational effects sponsors achieve through their sponsorship.

Research limitations/implications - The study indicates that the relational construct in the sponsorship literature should to a greater extent include sponsor-stakeholder relations, beyond the sponsor-club dyad, in a context of commercial immaturity.

Practical implications - The results indicate that club management should engage in stakeholder management with a strong focus on stakeholders of sponsors to provide value for these sponsors.

Originality/value - This study explores a new dimension to the relational construct of sponsorship, using the relational paradigm of brand management in a context of commercial immaturity. The mediating effect of the club is a contribution to the discourse on the relational construct.
\end{abstract}

Keywords Sponsorship, Value creation, Relationships, Football club management

Paper type Research paper

\section{Introduction}

Given the enormous popularity of football and the globalisation of the big European leagues, mainly driven by televised matches (Sandvoss, 2003), sponsorship in football has become an increasingly important ingredient in the marketing mix for companies (e.g. Jiffer and Roos, 1999). The popularity of top clubs and star players enables a wide reach for exposed brands. However, the majority of football activities take place in the shadow of these giants and brand exposure effects of sponsorship might not be as obvious as for the big clubs in the big leagues. This paper aims to capture this context, with limited expected exposure effects for sponsors, which will be represented by Swedish football and a study of how a club can provide value for their sponsors by means of a case study research strategy.

The development of football as a business has gone through a number of stages: foundation, codification, stratification, professionalisation, post-professionalisation, commercialisation and post-commercialisation (Beech and Chadwick, 2013). Football clubs in Sweden have traditionally been managed as member-based voluntary organisations with amateurism as a guiding ideal. Swedish football has, however, undergone a transition from stratification towards a higher degree of professionalism in terms of club organisation, but has not reached the stages commercialisation and post-commercialisation seen in bigger leagues

\footnotetext{
(C) Sven Junghagen. Published by Emerald Publishing Limited. This article is published under the Creative Commons Attribution (CC BY 4.0) licence. Anyone may reproduce, distribute, translate and create derivative works of this article (for both commercial and non-commercial purposes), subject to full attribution to the original publication and authors. The full terms of this licence may be seen at http://creativecommons.org/licences/by/4.0/legalcode
}

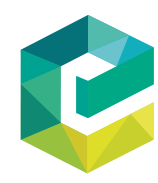

Sport, Business and Management: An International Journal Vol. 8 No. 4,2018 pp. $335-353$ Emerald Publishing Limited $2042-678 \mathrm{X}$ 
SBM

8,4

in Europe. This commercial immaturity of Swedish football depends on an amalgamation of numerous unfavourable conditions (Andersson and Carlsson, 2011). The general ideology of Swedish society with historical roots in the welfare state and a centralised model of sport upheld by national associations are seen as inhibiting factors for the transition towards commercialisation of Swedish football (Andersson et al., 2011). This social democratic welfare model and its influence on national associations - The Sports Confederation and the Football Association - support the notion of the non-profit organisation where all potential profits should be reinvested into football activities of the club (Carlsson and Backman, 2015).

Another consequence of this centralised model is that professional football clubs in Sweden are "owned" by members, due to regulations stipulating a minimum of 51 per cent ownership of members. This "majority rule" has an inhibiting effect on investor interests in Sweden and is seen as an important inhibitor of commercialisation of Swedish football (Andersson et al., 2011; Gammelsæter et al., 2011). It is, however, not the single decisive inhibitor as Swedish football is not as commercially mature as German, where the same ownership rule applies. A financial comparison between German champions FC Bayern München and Swedish champions Malmö FF (hereafter MFF) reveals this difference. Bayern München had a total operating revenue amounting to $€ 592 \mathrm{~m}$ in 2016 (KPMG, 2017) compared to the operating revenue of MFF amounting to $€ 23 \mathrm{~m}$ in the same period (Malmö FF, 2017). Even including participation in UEFA Champions League group stage, the operating revenue for MFF only amounted to $€ 50 \mathrm{~m}$ in 2015 (Malmö FF, 2017).

The slower pace of commercialisation can also be illustrated by comparing aggregate revenues of the European Leagues. The aggregate revenue in 2016 of the top 20 clubs in Europe amounts to $€ 7.4 \mathrm{bn}$ (Jones, 2017), while the aggregate revenue in 2016 of the 16 clubs in Allsvenskan only amounts to approximately €168m (Sahlström, 2017). Deloitte's Swedish football money report (Gozzi and Frountzos, 2014) supports the fact that comparable leagues all have higher revenues than the Swedish equivalent.

The broadcast revenues can be seen as a tentative indicator of the commercial exposure platform that a club can offer its sponsor. In the 2015/2016 season the "big five" league champions showed broadcast revenues ranging from Paris St Germain's €123m to FC Barcelona's €203m (KPMG, 2017). This can be compared to MFF's broadcast revenue amounting to $€ 22 \mathrm{~m}$ in 2015 when participating in the UEFA Champions League group stage and a modest $€ 1.2 \mathrm{~m}$ in 2016 when only competing domestically (Malmö FF, 2017). Compared to the "big five" leagues that benefit from significantly larger revenues from broadcasting and a huge interest outside the national TV market, commercial revenues accounts for a larger part in Swedish clubs (Gozzi and Frountzos, 2014). The average Swedish top tier club in 2016 gets 26 per cent of operating revenue from sponsors, which makes it an important source for operating income (Sahlström, 2017).

There are several examples of sponsoring being used without clear commercial objectives and management of sponsors have often supported their favourite sports club for patronising reasons (Nufer and Bühler, 2010; Otker, 1988). However, this specific patronising motive for sponsorship is not within the scope of this study. Historically, it has been a common motive for sponsors in Sweden, partly due to the above-mentioned ideology, resulting in a notion that it is morally suspicious to accept money from the market for commercial reasons (Andersson et al., 2011). However, in this transition that Swedish football undergoes, sponsors should strive for a shift from "sponsoring with your heart" to "sponsoring with your brain". This shift of focus from patronising motives to seeking commercial effects is, however, limited in Sweden. Clubs as well as sponsors seem still to be searching for actual value in the relationship, beyond mere philanthropy and charity. Therefore, the problem statement of this study is:

$R Q 1$. What value can football clubs provide for sponsors in a context of commercial immaturity? 
The study will approach this specific sponsorship context by means of a brand management notion. The assumption that exposure effects are subordinate will be explored and alternative explanations will be reviewed. The aim of this paper is therefore to show what value a football club can provide for sponsors in a context of commercial immaturity with limited expected exposure effects. In order to reach this aim the perceived value and expectations a sponsor has when engaging in a sponsorship agreement with a football club are to be explored. Also, the paper will explore in what way this club perceives its ability to fulfil these expectations in order to identify fits and misfits in expectations.

\section{Literature review}

Sponsorship is traditionally seen as a tool to strengthen brand awareness and brand image for the sponsor (Gardner and Schuman, 1988; Keller, 2003). Sponsorship of a club, an athlete, or a sports event, can be expected to generate positive effects on brand equity through, e.g. brand association (Jiffer and Roos, 1999). This literature review therefore has its point of departure in different brand management paradigms, proposed by Louro and Cunha (2001) along two axes: brand centrality and customer centrality as shown in Figure 1. Brand centrality concerns the focus of activities, where a low brand centrality has more focus on short-term activities and products and a high brand centrality has more focus on long-term activities and the brand is seen as more than just a mere instrument for communication. Customer centrality refers to the perception of to what extent customers take part in the process of value creation (Louro and Cunha, 2001).

The projective paradigm and the relational paradigm are both defined by a high brand centrality, which makes these two paradigms relevant. The reason for this is an understanding that positive effects from a sponsorship are dependent on long-term rather than short-term objectives in brand management. Even though it has been shown that typical shirt sponsor programmes are based on expectations on short-term returns (Chadwick and Thwaites, 2006), sponsorships of team-based sports with a large fan base are most likely concerned with long-term brand identification (Cornwell et al., 2005).
Football clubs as mediators

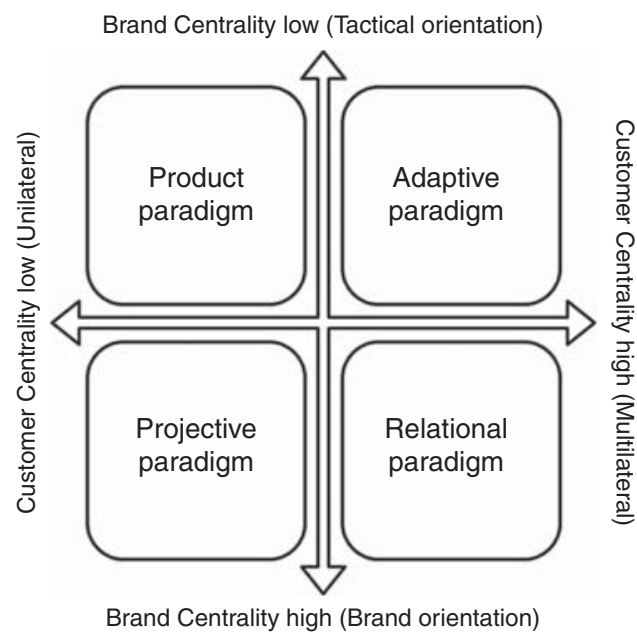

Source: Adapted from Louro and Cunha (2001)

Figure 1. Brand management paradigms 
SBM

8,4

338

Figure 2.

A generic projective exchange system

\section{The projective paradigm}

In the projective paradigm, a sponsor and a club can be regarded as analogue to an advertiser and media in an exchange system as shown in Figure 2.

The transaction between a sponsor and its customers drives the system. The sponsor wishes to expose its brand to customers in order to gain brand equity effects and ultimately generate transactions with customers (e.g. O'Keeffe and Zawadzka, 2011) and makes a choice of channel to expose its brand. If a club can provide an attractive enough content so that customers are willing to devote attention and engagement, a club can sell this attention and engagement as reach, frequency and impact to a sponsor (Goldschmidt et al., 2003).

Reach and frequency are quantitative measures, but impact is more qualitative in its nature and requires a match between chosen channel, what is communicated and target audience. The notion of brand management requires an understanding of the customer, not from a relational but a projective communicative viewpoint. In the case of sponsorships, this customer is the same for the club as for the sponsor. Considering the club being the vehicle - or media - for brand exposure, different levels of involvement with media as well as communication will affect the qualitative outcome of exposure (e.g. Ray, 1973; Vaughn, 1980; Wang, 2009). The concept of involvement in the literature does, however, not only address involvement with the media and message but also products as being high or low involvement products (e.g. Akbari, 2015; Spielmann and Richard, 2013). Responses to a certain message are depending on both situational and enduring involvement, i.e. both the immediate excitement and the long-term interest of the sport as such (Grohs et al., 2004; Tsiotsou, 2013). These different dimensions and levels of involvement can be related to the level of sociological and psychological attachment a consumer has in relation to a club (Beaton and Funk, 2008; Funk, 2008; Funk and James, 2001, 2006).

The football consumer market should therefore not be viewed as one homogeneous mass displaying identical consumer behaviour, but rather like any other consumer market where segmentation and classification of consumers is important (e.g. Mullin et al., 2014). A number of studies have classified sports fans in different categories demonstrating different motives for attending matches and following the club (e.g. Hunt et al., 1999; Tapp and Clowes, 2002). Commitment and consumer involvement shown by these different categories can range from the club being the way an active supporter expresses his or her identity to the entertainment consumer who is not so interested in the outcome of a match, but rather a total experience. This total experience is created not only by a football event on the pitch but also by fanatic supporters, hence becoming customers and co-creators of the same event (Mehus, 2010). Other factors that attract non-regular spectators are uncertainty of the outcome of the match (Forrest and Simmons, 2002), form of the team and attractiveness of the opponent team (Cross and Henderson, 2003). Cross and Henderson (2003) claimed that events during

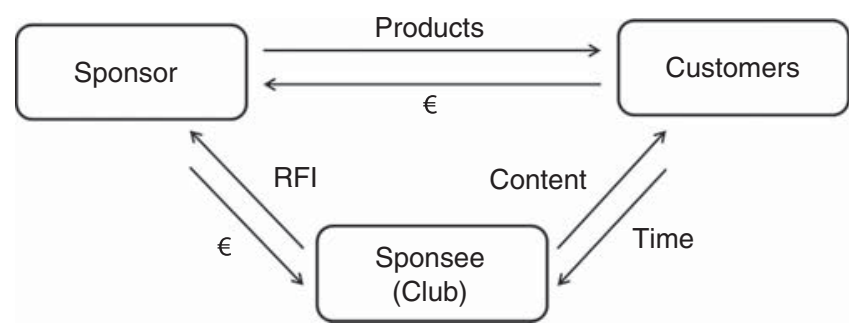

Source: Adapted from Goldschmidt et al. (2003) 
match day do not affect gate takings but van Uden (2005), however, claimed the opposite and presented the idea of the football club as a "total experience" entertainment company managing the experience not directly related to the event on the pitch.

A typical way of claiming value for sponsors in Swedish football is to offer exposure on team shirts, which often leads to a high number of visible sponsors. However, this is a quite harmful path to follow since it has a negative effect on club image and is wasteful for individual sponsors (Mikhailitchenko et al., 2012). Exposure on match day has a positive effect on sponsor brand loyalty (Vale et al., 2009), but it is quite important to strive for a balance between number of sponsors and potential turnover when attracting sponsors. This argument is equally important for sponsors who benefit more, in terms of brand equity, from more exclusive sponsor arrangements (Donlan, 2014). Exposure effects are also depending on previous brand experiences resulting in that exposure of a known brand on match day will have a stronger effect than for a less known brand (Breuer and Rumpf, 2011).

Apart from building brand awareness and image, sponsorship has been recognised for its potential to achieve multiple objectives. It can be used to gain competitive advantage, to access the network a team offers, develop and retain relationships with customers and staff, for entertainment for stakeholders or to enhance a firm's ability to engage with the community (Farrelly and Greyser, 2012; Henseler et al., 2011; Masterman, 2007). Sponsorships are sometimes also used to increase credibility of a company, which typically are sponsors that are official supplier of a team, such as kit sponsors (Ferrand et al., 2007). This credibility is to a large extent affected by the perceived sincerity in engaging in the sponsorship agreement (Demirel and Erdogmus, 2016). Furthermore, non-consumers are also often targets, including employees, channel members, community and even competitors with the aim to block opportunities for a competitor to sponsor (Thompson and Speed, 2007). Furthermore, perceived alignment of sponsor and sponsored club is one central dimension in the "Brand Image Transfer" model proposed by Smith (2004). This strategic fit between the sponsor and sponsee has in a number of studies been shown to be an important dimension in generating a favourable attitude towards the sponsor (Becker-Olsen and Hill, 2006; Cornwell et al., 2005; Donlan, 2014; Grohs et al., 2004; Lacey and Close, 2013; Woisetschläger et al., 2017; Zaharia et al., 2016). A lack of fit, e.g. a naming partner not having a fit with the club identity, can on the other hand lead to negative reactions among highly identified supporters of the club (Reysen et al., 2012).

\section{The relational paradigm}

Sponsorships have evolved over the years, and companies have started to work more actively with commercial sponsorship and sponsorship is becoming described as a relational construct (Bühler et al., 2009; Farrelly et al., 2006). Not only dyadic sponsor-sponsee relationships are important, but also relationships between sponsors and the effects of a sponsor having relationships with more than one sponsee (Chanavat et al., 2016). The relationships between sponsors are mostly important in the organisation of sponsorship networks arranged by some clubs, as studied by Wagner et al. (2017).

It has been concluded that commitment in the relationship is a key determinant for success, superseding traditional B2B relationship constructs as trust and effective communication (Bühler et al., 2007). These findings are aligned with the studies of Farrelly et al. (2003) who concluded that trust in the relationship is depending on commitment to the relation, rather than being a determinant for success in itself. This relation between commitment to the club and the orientation towards brands sponsoring the club has also been shown by Shaw and McDonald (2006), which, in turn, implies that a successful relationship to sponsors is also depending on a successful management of the relationship with committed supporters. An important component of this relationship is the customer engagement of these supporters which can contribute with a multitude of effects such as 
SBM

8,4

word of mouth, co-creation of experiences and active behaviour in social media affecting the attitudes of other customers (Verhoef et al., 2010). The potential engagement generates value by means of the following mechanisms: purchasing, referral, influence and knowledge (Kumar et al., 2010). It could be argued that this is not a part of the relational paradigm of brand management per se. The argument is not concerning the relationship between sponsor and the sponsor's customers but the relationship between sponsor and the club. This sponsor-club relationship is strengthened by the relationship between club and the sponsor's customers, which is another dimension of strategic fit discussed under the projective paradigm.

It has, however, been argued that a broader view of relationships between sponsor and club should be adapted, in order to include external as well as internal contexts (Cousens et al., 2006). Furthermore they also argue that value-added benefits of both parties and the continuum of relationships are essential for understanding sponsor-club relations (Cousens et al., 2006). This continuum is found to be depending on inter-personal relationships rather than inter-organisational relationships and fulfilment of mutual and individual expectations on the sponsor agreement (Morgan et al., 2014). Sponsorship relationships are going through a life cycle including three stages: formation, operation and outcome. In the transition between these stages, there is a risk of termination of the sponsorship agreement due to lack of mutual expectations (Urriolagoitia and Planellas, 2007). An extensive literature review conducted by Walraven et al. (2012) identify studies that have shown that a sponsorship can strengthen the sponsor's relation with other stakeholders, but this finding mainly applies to sponsors operating in a $\mathrm{B} 2 \mathrm{~B}$ market, activating the sponsorship in relation to their customers. Activation through community-related activities has also been shown to have a greater effect on sponsorship outcomes than what can be measured through traditional advertising proxy measures (Vance et al., 2016).

\section{Concluding remarks}

The notion of value beyond patronising reasons in a sponsorship relation has developed from projective to more relational constructs. The focus in literature is, however, mostly on the relationship dyad involving sponsor and club. It could hence be argued that the relational discourse on sponsorship still is an expression of the projective paradigm of brand management, exploiting the relation with the sponsee in order to gain brand projection effects. According to Louro and Cunha (2001), the relational paradigm is the most strategically viable approach to long-term brand equity. In the commercially immature context of this study, the exposure effects are expected to be limited, as discussed above. Therefore, the relational paradigm of brand management might offer an explanation to why a sponsor chooses to engage in a sponsorship agreement with a club. This, in turn, implies that there is room for a contribution to expand the relational construct in the sponsorship literature beyond the $\mathrm{B} 2 \mathrm{~B}$ relationship between sponsor and club and also include the relationship between sponsor and its customers. The literature review has pointed towards a number of concepts that can be seen as important when discussing long-term brand management effects based on the two paradigms. In order to explore this empirically, the following identified concepts are to serve as guiding for the empirical study:

- the strategic fit between sponsor and sponsee;

- the perceived potential for a long-term relationship between sponsor and customers, as well as between sponsor and sponsee;

- the perceived role of activation and leverage for value creation in the sponsorship agreement; and

- even though at beforehand expected to be limited, the expected exposure effects. 
Method

This study is based on a single case study research strategy (Yin, 2014) and is founded in an interpretivist research philosophy (Saunders et al., 2016). This philosophy contributes to the understanding of the nature of long-term dyadic strategic relationships between sponsors and a football club. The case chosen is MFF, one of the leading clubs in Swedish football. As argued above, Swedish football is in a transformation process experiencing a tension between determinants of commercial immaturity and a pressure for commercialisation. Since this study is not addressing sponsorship motives based on a strong emotional link to the club, MFF is chosen being a forerunner in the Swedish process towards professionalism. This forerunner status is further elaborated upon in the introduction to the case below. The empirical material for this study was collected during the 2014 season.

Insights were gathered from both sides of the sponsorship dyad by means of non-structured interviews (Brinkmann and Kvale, 2015; Saunders et al., 2016) with key decision makers from main sponsors and the football club. Main sponsors are defined as the sponsors that are expected to have a long-term commitment towards the club in their roles as naming partner, kit sponsor, kit supplier and official partners, as shown in Figure 3 in the next section. Sponsors at lower levels have been deemed out of the empirical scope due to an expression of more short-term agreements with the club. An overview of respondents is shown in Table I.

In total, seven interviews were conducted. The respondents were chosen based on their decision-making capacity in the sponsor companies, and their decision-making capacity and expertise in the club. The non-structured interviews all had a duration of approximately $1.5 \mathrm{~h}$. They were conducted in face-to-face meetings in the office premises of the respondent, with one exception; the Puma marketing director, with whom the interview was conducted in the Puma corporate lounge at MFF's home stadium: Swedbank Stadium. The starting point for interviews was the overall concepts resulting from the literature review, with openness for emerging topics defined by outcomes of interviews with respondents. Each concept, or interview theme, was introduced with an opening question. Depending on the response, probing questions were asked until a perceived saturation on the topic was achieved. In the context of the interview, the main points expressed by the respondent was noted and also presented to the respondent immediately for confirmation. Additional notes

\begin{tabular}{|c|}
\hline Naming right Partner \\
\hline Kit Sponsor \\
Official Partners \\
\hline The Network \\
Club Seats \\
\hline
\end{tabular}

Football clubs as mediators

Figure 3. Sponsor structure 2014

\begin{tabular}{lll}
\hline Organisation & Respondent's role & Role in dyad \\
\hline Malmö FF & Sales director & Club \\
Malmö FF & Communications director & Club \\
Malmö FF & Supporter liaison officer & Club \\
Swedbank & Marketing director & Naming right partner and official partner \\
Puma & Marketing director & Kit supplier \\
Rörläggaren & Managing director & Kit sponsor \\
Sydsvenskan & Marketing director & Official partner
\end{tabular}

Table I. List of respondents 
SBM 8,4

on the context of interviews did not suggest any deviations from the intended interview setting. The interview guide is presented in the Appendix.

In line with the interpretivist philosophy, the resulting themes in the analysis were not predefined but rather emerged in a process of data collection and analysis in an abductive approach (e.g. Reichertz, 2009). Hence, the empirical emergence of themes is not to be confused as a true grounded theory approach (e.g. Charmaz, 2014) where themes are conceptualised purely on empirical findings and where data from interviews are coded according to a strict procedure. Instead, the analytical strategy builds on the notion of thematic networks (Attride-Sterling, 2001) where the final conclusion in the discussion - the global theme - is an aggregation of organising themes, in turn, defined by an aggregation of basic themes. The basic themes were defined based on the empirical material from interviews together with the identified concepts from the literature review. This can be exemplified with the organising theme Locality, which is an aggregation of the following basic themes: Being part of something greater, Local community projects, Strategic fit and Local networking. The analytical focus was to identify commonalities among sponsors regarding motives for engaging in a long-term sponsorship commitment and to identify alignment or lack hereof with the other part of the dyad, the club. In research of this nature, with an interpretative approach to analysis (Burrell and Morgan, 1994), it is a subjective choice made by the researcher how to code data and how to choose thematic dimensions to tell the case story.

\section{MFF - an introduction to the case}

MFF was founded back in 1910 with football as the only sports discipline in the club. A number of other disciplines were later introduced, but as of today the club has again focussed on football only. Swedish football has a long tradition of amateurism, and professionalism is a relatively new concept in Sweden in comparison to other countries in Europe. MFF was the first club in Sweden introducing a complete squad of professional players in the team back in 1989.

The year 1999 marked another turning point for MFF in terms of professionalism. The club was relegated from Allsvenskan and played in the second tier league for the first time since 1933. This relegation was seen as disastrous and induced a process towards a comprehensive sponsor strategy. The goal was clear; MFF should be promoted to the top tier league again immediately. In this process, "The Network" (Nätverket) was born, a number of local companies joining forces to strengthen the financial platform for the club to realise this goal. Many sponsors involved were joining because of a strong emotional relation to the club, which was more or less symptomatic for all sponsors of the club. During this period, volume was seen as a success factor, but later, it was realised that mass sponsorships would not be a sustainable business model for the club. MFF therefore changed their sponsor strategy in relation to the opening of a new stadium in 2009:

We are deliberately focusing on long term sponsorship and partner agreements, where sponsors make decisions with their brain rather than with their heart (Interview with MFF Sales Director).

Before this deliberate change, as many as 144 sponsors were exposed at the same time in the stadium. The 2009 policy explicitly stated that a maximum of 16 sponsors are exposed in the stadium on match day, ranging from naming rights of the stadium to official partner status.

During the 2012 season, MFF did not have a kit sponsor, which was highly appreciated by many devoted fans seeing this as a manifestation of traditional football ideals far away from the post-modernity of today's football. It can also be seen as highly remarkable that a top tier club does not have any kit sponsor for a whole season. The reality is that MFF overestimated the sponsor market and the premium price which could be charged in 2011, including exposure in the UEFA Champions League and Europa League, was seen as too 
high for potential sponsors in 2012. It should, however, be noted that the price was quite low in comparison to European standards:

We asked for approximately one million $€$, but I have now realised that it was overestimated and that the realistic price is around half a million $€$. We are to make efforts to sell it for 2013, but we are not to scrawl the shirts full with logos (MFF Managing Director during an open meeting for members, November 2012).

MFF managed to attract a kit sponsor for 2013 and 2014 without compromising on the price level. Rörläggaren, a locally anchored company which was a part of "the Network", upgraded its partner status with an ambition to also engage in community projects together with MFF.

Before the 2014 season, additional changes to the sponsor structure were made. The concept of tribune sponsors was removed and eight official partners now shared the exposure on the four tribunes of the stadium, leading to a sponsorship structure shown in Figure 3. Another important change was that these sponsors are now exposed with white logos on a blue background, the colour of the MFF club crest. This change was announced at the general assembly in the club in the beginning of 2014, resulting in standing ovations from attending members of the club.

\section{The organising themes for club-sponsor relations}

The organising themes that will be accounted for are as stated above a result of the analysis of interviews, which is done by an identification of basic themes resulting in organising themes. The organising themes are based on the literature review as well as empirical findings from interviews with sponsors as well as MFF. The three organising themes to be presented are: Exposure, Locality and Activation. Exposure is found to be playing a subordinate role in the perceived value for sponsors. The club, however, believes that they do indeed offer an exposure value that can measured with traditional brand valuation metrics. Locality refers to the way the club with its local anchorage can serve as a platform for the sponsor to nurture its relationship with stakeholders in the local community. Finally, Activation refers to the way sponsors can activate the sponsorship by means of activities that go beyond the traditional exposure mechanisms in a sponsorship.

\section{Exposure}

The first organising theme is that of exposure. In comparison, there is a vast difference between Allsvenskan, the Swedish top tier league, and the major European leagues. Manchester United has a shirt sponsorship deal with General Motors, which will generate over $€ 400 \mathrm{~m}$ over seven years. The former shirt sponsor Aon still remains a partner with naming rights for the club's training facility (Jones, 2014). In this case, the level of exposure is obvious, given the global popularity of Premier League in general and Manchester United in particular. Allsvenskan and the individual clubs in Sweden can never compete in neither exposure nor popularity. Even though it is claimed that everyone in Malmö has some kind of opinion about MFF, it is hard to compete even on a local level for commitment of fans:

We do not just compete with other Swedish clubs for fandom, but rather with the larger international clubs from the big leagues in Europe. You see more Barca and Chelsea jerseys in schools than ours (Interview with MFF Communications Director).

The question is then to what extent exposure on a more local or regional level actually provides value for sponsors. One expected effect of the new sponsor policy which MFF labels "less is more" is that of a higher effect of sponsor exposure:

We do measure the effect of exposure on match days regularly and report back to our official partners. We believe that we then can prove a value of exposing the sponsors' brands (Interview with MFF Sales Director).
Football clubs as mediators

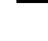


SBM

8,4

The measurement and reporting of exposure and the corresponding effect on sponsors' brand equity in monetary terms are carried out by a third-party market research service provider:

We get these regular exposure reports from MFF, where we also get a calculated monetary value on our brand equity based on the exposure. To be perfectly honest, I have no idea if the exposure leads to an actual increase of sales, but it is still nice to get the reports (Interview with Swedbank $344 \quad$ Marketing Director).

It is a common understanding among significant sponsors that a mere exposure is not the main rationale behind the sponsorship. Most sponsors have strong brand equity in advance, and the reasons for sponsoring are to be found in other areas than exposure. The kit supplier, PUMA, is focussing a lot on football as one of their key sports markets. In their case, it is natural for them to partner with selected clubs, where PUMA can expect a positive brand association. The exposure that is included in the partnership is actually perceived to play a subordinate role:

To be perfectly honest, we have such high brand awareness to begin with, so the exposure we get in the stadium does not necessarily contribute to brand awareness, but rather as a gentle reminder that we have the kit supplier partnership with MFF (Interview with PUMA Marketing Director).

MFF gradually harmonised exposure of sponsors with the club profile. In 2011, supporters reacted strongly to a kit sponsor who insisted on having their logo in red on the shirts. This decision was revoked by the sponsor after intense pressure from MFF supporters and the logo was thereafter presented in white on the shirts. Before the 2014 season, all banner exposure on stands in the stadium is with white logos on a blue background, which has been welcomed by supporters and members of the club. Even though there was some initial resistance among official partners, there is today a common understanding that this harmonisation strengthens the association with the club:

Actually, it is not a big deal for us if we have the logo in original colours or in white. It is not rocket science, our name says it all, regardless of what colour it is presented in. It looks nice to harmonise with the club colours (Interview with Rörläggaren Managing Director).

It can be concluded that even though MFF is one of the most exposed clubs in Sweden, sponsors are not considering exposure as a dominant motive for sponsorship. This does not imply that they have engaged in partnership for patronising reasons, or pure charity, there are quite elaborate reasons for sponsoring MFF which will be discussed in the following organising themes.

\section{Locality}

An organising theme emerging from the interviews is that of locality, the local anchorage. Given the successful history of MFF, the club creates a lot of involvement in Malmö and surrounding areas:

The reason for us to be an official partner is that MFF is a significant part of Malmö. We want to be seen as the same, so it is natural for us to associate ourselves with them (Interview with Sydsvenskan Marketing Director).

The naming right partner, Swedbank, is not just operating in the local market, but internationally. Swedbank is actually partner on two levels, to make sure to involve local branches in Malmö. This local commitment is stressed as important for the partner:

MFF represents something important locally; therefore it is natural for us to engage in MFF locally as an official partner. The decision to become naming right partner was made on national level, but we also want to be active locally (Interview with Swedbank Marketing Director). 
If we make a comparison to the organising theme of exposure, one could claim that this is just another way of discussing exposure. However, exposure effects for sponsors of Swedish football are typically defined as short-term awareness effects, whereas effects discussed here are more in terms of expected long-term brand association. MFF, being a successful team, is seen as a representation of a successful city and region in growth. There are expectations of positive association effects. All interviewees express that "we want to be a part of this success".

From a supporter perspective, the element of locality is important. A strong association with local anchorage is an important aspect of general fandom for MFF. The 2011 example of the kit sponsor with a red logo mentioned earlier had more dimensions than the mere colour of the logo. The same sponsor also sponsored other top rival clubs in Sweden, and a part of the discourse among supporters in social media questioned the sponsor as not being locally rooted, but representing "the others". Even though there is a general strong resistance against any visual representation of commercial interests in relation to the club among fanatics, there is a tendency towards a higher level of acceptance of sponsors with a local anchorage.

An aspect of being a club with a lot of attention is media coverage, not just reporting of sports results, but also reporting of news about the club in general, in positive as well as negative terms. One official partner is Sydsvenskan, the dominant regional morning paper, who has to balance the role of the commercial interest in the club with the reporting role of independent press. The key tension that emerges is when the newspaper reports negatively about the club that the same newspaper commercially associates itself with:

We have to deal with this internally and separate the roles in the organisation. We in the marketing department might find negative articles about MFF unfortunate, but we need to maintain the ideal of the independent free press. It is just part of the daily life in a newspaper that the commercial and editorial management might disagree on certain issues but also manage disagreement professionally (Interview with Sydsvenskan Marketing Director).

There is indeed a high level of media coverage for MFF, for good and for bad. There have been several occasions with incidents involving dysfunctional supporters and social problems surrounding the club's activities. Sponsors are, however, not concerned that their brand is damaged due to an association with negative aspects of the club. The important aspect is that MFF as a club is explicit about values and measures taken with ambition to counteract. As long as MFF explicitly acts as a responsible entity in the local community, the relation is not damaged. This has, however, at occasions led to conflicts between club and supporters, since restriction measures taken have been seen as collective punishment of many because of a dysfunctional behaviour of a few.

It could be argued that football clubs always have taken a social responsibility in their own community, by, e.g., organising sports activities for the youth population. However, social responsibility is not just about a public health project, but goes beyond this.

MFF consider themselves having a strong responsibility to engage in community issues. A strong ambition is to be not just the club of Malmö, but also the club of Scania, an administrative province in southern Sweden. One means to achieve a higher level of engagement outside Malmö is to play friendly matches and U21 matches in smaller towns around Scania. There is also a belief that a strong commitment in the local community can help prevent some negative aspects and social problems in relation to football fandom:

As a membership based organisation, one could state that we have a community responsibility by default (Interview with MFF Supporter Liaison Officer).

Apart from reactive responses to problems, MFF also engages in proactive social commitment. Previously, MFF has not communicated any social activities externally, with 
SBM

8,4

quite limited influence on the relationship with stakeholders. In 2010, a decision was made to organise all social activities in an overall programme: MFF $i$ Samhället (MFF in Society).

The shirt sponsor during the time of this study, Rörläggaren, is a company within the plumbing industry, locally anchored in Malmö, with a national presence in the market. This sponsor is quite explicit about societal motives behind being a sponsor of MFF. They were not initially approached by MFF to become a sponsor, it was the owner and managing director who came up with the idea to become a sponsor and use the partnership to leverage social activities they already were engaged in:

I made this presentation for the MFF board of directors, where I tried to make them understand that I was not really interested in traditional sponsoring, but to engage in a partnership for social projects. I am not sure if they got it, it felt like they most likely saw me as a pocket full of money, and hoped for a transaction (Interview with Rörläggaren Managing Director).

A win-win situation was gradually been built up, where Rörläggaren and MFF jointly increased their social community activities:

I think that we are kind of annoying for MFF in Society, we are constantly bombarding them with requests to initiate even more social activities (Interview with Rörläggaren Managing Director).

The other interviewees mention the importance of community activities as well, but explicitly state that they do not live up to the same publically known activity level as Rörläggaren, who considers this to be the main activation of their sponsorship.

\section{Activation}

MFF occasionally adds extra events to the total experience at the stadium together with sponsors activating their sponsorship in relation to matches. These activities have had a positive effect in relation to casual supporter categories, but there are issues in relation to fanatics. A strong opinion has been observed among significant fanatics, who express scepticism about events that are not aligned with their traditional view of football. However, there is a strong common understanding that activation of sponsorships is important:

I really think that in general, Swedish sponsors are not activating their sponsorships to their full potential. There is much to be done which would generate marginal value for sponsors (Interview with MFF Sales Director).

Activation of sponsorships does not only involve activities in and around the stadium on match days. The interviewed sponsors all stressed the importance of activation, but with different activities:

We definitely want to go beyond mere exposure. We have experienced that customer services have been asked whether a subscription for the coming year would imply a possibility to get discounted tickets for the matches next year as well (Interview with Sydsvenskan's Marketing Director).

This activation is directed to consumers, not necessarily to drive sales, but to mark that Sydsvenskan is strongly associated to MFF. If a consumer chooses to associate him or herself with Sydsvenskan, they then provide consumers with an association to MFF as well. Swedbank does not seek a direct increase in sales or reduction of customer churn, but use the sponsorship as a platform for a continuous interaction with companies involved in the MFF Network:

Our partnership with MFF gives us the opportunity to be quite visual in the MFF Network, when they organise Network activities. I am not sure what the precise effects are, but I believe these are more important than being visible in the Stadium (Interview with Swedbank Marketing Director).

PUMA, on the other hand, clearly see commercial targets with activation. All brand association effects are seen as marketing, but activation is related to sales. PUMA delivers 
equipment not only to the top tier team but also to all youth teams in the club which is one of the sought-after effects of the sponsorship. This effect can be achieved with any club having a substantial level of activity in youth teams, but in these cases brand association effects are excluded. This sales activity is always done with a third-party retailer:

We would never go into a kit supplier relation with MFF without a third party relation with a sports goods retailer. In that way we can use our sponsorship to drive sales directly (Interview with PUMA Marketing Director).

As has been mentioned before, Rörläggaren engages in social community projects jointly with MFF, which is activation in itself:

Our sponsorship builds on activities, not exposure. The most important part for us is the ability to work jointly in social projects (Interview with Rörläggaren Managing Director).

The brand association believed to be built up does not have an effect on commercial results for Rörläggaren directly, but their engagement in social projects has become much more visible by means of their partnership with MFF.

Activation might, together with locality, be the most important aspect of sponsoring MFF. Activation can lead to a better relation to sponsors' target groups, but in different ways for different target groups. Using the classification of spectator segments, it could be argued that a reduction of ticket prices is mainly directed towards casuals, who would otherwise not attend a match and that Network activities are directed towards regulars. On the other hand, activation is not necessarily directed towards fanatics, who are mainly interested in the game as such, and activation can actually have negative effects in this segment. However, PUMA and MFF managed to activate the relation to fanatics in the beginning of 2014, engaging a lot of fanatic supporters. It was time to design a new away kit, to supplement the sky blue home kit. A design competition was announced, and MFF and PUMA received a vast amount of suggestions from devoted supporters, to whom the design of the kit is important as a representation of club identity. The new away kit, called star bright, was still "sky blue" but midnight blue, and was generally received with enthusiasm among fanatic supporters.

\section{Conclusions and implications}

$\mathrm{MFF}$ has made numerous efforts in order to professionalise club-sponsor relations over the last years resulting in a sponsor policy claiming a higher level of professionalism. They want to engage with sponsors that will sponsor "with their brain rather than with their heart". In order to really exploit this, the club has to offer a concrete value for sponsors, and also be selective in what sponsors to engage with.

In 2014, there were five levels of sponsorships in MFF, and this study includes the three top levels. It might be so that sponsors in the MFF Network and club seat sponsors today have more direct commercial incentives for engaging, as argued by Wagner et al. (2017), but the three top levels do not see direct commercial value in monetary terms but rather relational effects. Traditional exposure measures do not necessarily imply a value for MFF top-level sponsors, a value which is also hard to measure (Breuer and Rumpf, 2011). The main reason for engaging with MFF is local anchorage. There is a lot of symbolism related to the club, its colours and the stadium, which are seen as representations of the city. Even though the club wants sponsoring with the brain, sponsors seem to still sponsor with their heart, or at least valuing emotional and relational values before transactional. Sponsors see their partnership as a possibility to make a statement about their own ambitions to be a part of what is important for the city, in different ways, which, in turn, has a positive effect as argued by Demirel and Erdogmus (2016). It is to be noted that it is not just through exposure, but through activation of sponsorships as described above. The club therefore
Football clubs as mediators 
SBM

8,4

348

eeds to take these activation opportunities into account when building up relationships with sponsors, and at the same time sponsors need to clearly express what value they seek in the relationship.

To associate with the club is not just about an association with the top tier team, but the club as a whole. The club is not a pure commercial entity, but a membership-based club, meaning that many supporters are also "the club" in capacity of their membership. The membership-based football club has a portfolio of objectives to fulfil where, in contradiction to traditional companies, financial performance serves as a means rather than a goal in itself. These objectives are not always aligned, and the relation to sponsors, supporters and other stakeholders becomes complex.

Based on the above presented organising themes and revisiting the conclusion from the literature review - a potential need to expand the relational construct of sponsoring beyond the $\mathrm{B} 2 \mathrm{~B}$ relationship between sponsor and club - the global theme of this study is Mediating stakeholder relations.

\section{Mediating stakeholder relations}

The football club will be able to function as a mediator in the relationship between sponsor and this sponsor's stakeholders, if the club itself nurture its own relationship with the same stakeholders, as illustrated in Figure 4. Note that the traditional notion of the relational paradigm in brand management takes its point of departure in sponsors' relations with customers but in this context of commercial immaturity, relations with additional stakeholders are equally interesting. An immediate implication for club management is that of stakeholder management as a part of sponsor relations management. In a more mature commercial context the club can focus more on the direct relationship in the dyad with a sponsor, in order to maximise effects on brand equity, but in this context of commercial immaturity a wider focus is needed. Hence, the notion of strategic fit expressed in the literature review is extended, beyond a focus on commercial objectives, to also include an emphasis on alignment in complex stakeholder networks.

\section{Limitations and further research}

The first limitation I would like to address is the time aspect in this study. It provides a snapshot picture of motives for engaging in, and the expected value of, a sponsorship agreement. MFF was chosen as a case given the club's status as a forerunner in terms of professionalisation of Swedish football. The club was in 2014 in a transition towards even further professionalisation, and took significant steps in 2015 and 2016. In 2014, the club only competed domestically, but qualified for the group stage in UEFA Champions League in 2015 and 2016. The exposure effect, nationally and maybe even internationally, can be expected to have increased. I would, however, argue that the case still provides an understanding of sponsorships in the context of commercial immaturity given the situation the club was in, back in 2014. A suggested area for further research would therefore be to study the transition as such, to study the extent of which sponsors' motives and

Figure 4.

Football clubs as mediators in stakeholder relations for sponsors

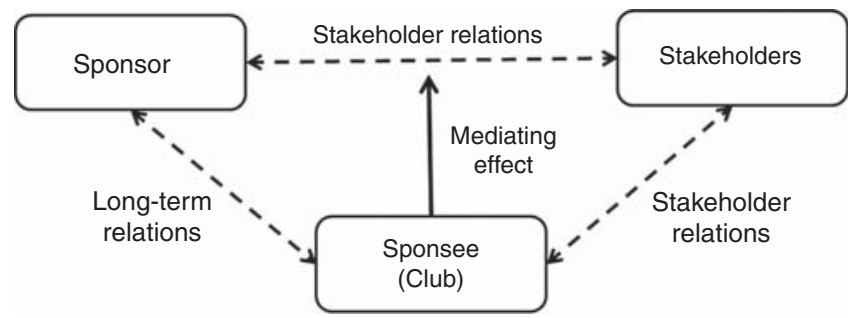


expectations on the effects have actually changed due to the transition towards postprofessionalisation and maybe even commercialisation.

Only relationships with the three top layers in the sponsor structure have been studied, which is a limitation as well. The original rationale for companies engaging in the MFF Network was stated - in the introduction to the case - to be more of a patronising nature, but this might also change due to the transition. This is also an area for future research, to study how local sponsor networks can benefit from this transition.

The third and final limitation I would like to address is that this paper only addresses motives and expectations, and not actual effects. The viewpoint of members and supporters is only illustrated empirically by means of secondary data, mainly texts from social media published by engaged supporters, but also insights provided by MFF staff. The actual value of the mediation of a sponsor's relationships to stakeholders is not studied, which is the third area for future research. Sponsors expect a value in terms of mediation of relationships with stakeholders, but the room for further research is to study to what extent stakeholders share this perception of value.

\section{References}

Akbari, M. (2015), "Different impacts of advertising appeals on advertising attitude for high and low involvement products", Global Business Review, Vol. 16 No. 3, pp. 478-493.

Andersson, T. and Carlsson, B. (2011), "A diagnosis of the commercial immaturity of Swedish club football”, Soccer \& Societv, Vol. 12 No. 6, pp. 754-773.

Andersson, T., Backman, J. and Carlsson, B. (2011), "Sweden: the development of club football on the periphery of Europe", in Niemann, A. García. B. and Grant, W. (Eds). The Transformation of European Football - Towards the Europeanisation of the National Game, Manchester University Press, Manchester, pp. 187-203.

Attride-Sterling, J. (2001), "Thematic networks: an analytical tool for qualitative research", Qualitative Research, Vol. 1 No. 3, pp. 385-405.

Beaton, A.A. and Funk, D.C. (2008), "An evaluation of theoretical frameworks for studying physically active leisure”, Leisure Science, Vol. 30 No. 1, pp. 53-70.

Becker-Olsen, K.L. and Hill, R.P. (2006), "The impact of sponsor fit on brand equity: the case of nonprofit service providers", Journal of Service Research, Vol. 9 No. 1, pp. 73-83.

Beech, J. and Chadwick, S. (2013), "Introduction: the commercialisation of sport", in Beech, J. and Chadwick, S. (Eds), The Business of Sport Management, 2nd ed., Pearson, Harlow, pp. 3-23.

Breuer, C. and Rumpf, C. (2011), "Memorization of sport sponsorship activities: the case of the German Bundesliga", Sport. Business and Management: An International Iournal, Vol. 1 No. 3, pp. 284-293.

Brinkmann, S. and Kvale, S. (2015), InterViews: Learning the Craft of Qualitative Research Interviewing, 3rd ed., Sage, Thousand Oaks, CA.

Bühler, A., Chadwick, S. and Nufer, G. (2009), Relationship Marketing in Sports, ButterworthHeinemann, Oxford.

Bühler, A.W., Heffernan, T.W. and Hewson, P.J. (2007), "The soccer club-sponsor relationship: identifying the critical variables for success", International Journal of Sports Marketing \& Sponsorship, Vol. 8 No. 4, pp. 291-309.

Burrell, G. and Morgan, G. (1994), Sociological Paradigms and Organisational Analysis, Ashgate, Surrey.

Carlsson, B. and Backman, J.P. (2015), "The blend of normative uncertainty and commercial immaturity in Swedish ice hockey", Sport in Societv, Vol. 18 No. 3, pp. 290-312.

Chadwick, S. and Thwaites, D. (2006), "Distinguishing between short-term and long-term commitment in football shirt sponsorship programmes: towards a matrix of management implications", International Journal of Sports Marketing \& Sponsorship, Vol. 7 No. 3, pp. 163-179.

Chanavat, N., Desbordes, M. and Dickson, G. (2016), "Sponsorship networks: toward an innovative model", Sport. Business and Management: An International Journal, Vol. 6 No. 4, pp. 424-439.

Football clubs

as mediators 
SBM

8,4

Charmaz, K. (2014), Constructing Grounded Theory, 2nd ed., Introducing Qualitative Methods, Sage, Los Angeles, CA.

Cornwell, T.B., Weeks, C.S. and Roy, D.P. (2005), "Sponsorship-linked marketing: opening the black box", Journal of Advertising, Vol. 34 No. 2, pp. 21-42.

Cousens, L., Babiak, K. and Bradish, C.L. (2006), "Beyond sponsorship: re-framing corporate-sport relationships", Sport Management Review, Vol. 9 No. 1, pp. 1-23.

Cross, J. and Henderson, S. (2003), "Strategic challenges in the football business: a SPACE analysis", Strategic Change, Vol. 12 No. 8, pp. 409-420.

Demirel, A. and Erdogmus, I. (2016), "The impacts of fans' sincerity perceptions and social media usage on attitude toward sponsor", Sport. Business and Management: An International Journal, Vol. 6 No. 1, pp. 36-54.

Donlan, L. (2014), "An empirical assessment of factors affecting the brand-building effectiveness of sponsorship", Sport. Business and Management: An International Iournal, Vol. 4 No. 1, pp. 6-25.

Farrelly, F. and Greyser, S. (2012), "Sponsorship linked internal marketing", Lournal of Sport Management, Vol. 26 No. 6, pp. 506-520.

Farrelly, F., Quester, P. and Burton, R. (2006), "Changes in sponsorship value: competencies and capabilities of successful sponsorship relationship", Industrial Marketing Management, Vol. 35 No. 8, pp. 1016-1026.

Farrelly, F., Quester, P. and Mavondo, F. (2003), "Collaborative communication in sponsor relations", Corporate Communications: An International Iournal, Vol. 8 No. 2, pp. 128-138.

Ferrand, A., Torrigiani, L. and Povill, C.A. (2007), Routledge Handbook of Sports Sponsorship, Routledge, Oxon.

Forrest, D. and Simmons, R. (2002), "Outcome uncertainty and attendance demand in sport: the case of English soccer", Journal of the Royal Statistical Society: Series D (The Statistician), Vol. 51 No. 2, pp. 229-241.

Funk, D.C. (2008), Consumer Behaviour in Sport and Events: Marketing Action, Elsevier, Oxford.

Funk, D.C. and James, J. (2001), "The psychological continuum model: a conceptual framework for understanding and individual's psychological connection to sport", Sport Management Review, Vol. 4 No. 2, pp. 119-150.

Funk, D.C. and James, J.D. (2006), "Consumer loyalty: the meaning of attachment in the development of sport team allegiance", Journal of Sport Management, Vol. 20 No. 6, pp. 189-217.

Gammelsæter, H., Storm, R.K. and Söderman, S. (2011), "Diverging Scandinavian approaches to professional football", in Gammelsæter. H. and Senaux. B.(Eds). The Organisation and Governance of Top Football across Europe: An Institutional Perspective, Routledge, Oxon, pp. 77-92.

Gardner, M.P. and Schuman, P. (1988), "Sponsorships and small business", Journal of Small Business Management, Vol. 26 No. 4, pp. 44-52.

Goldschmidt, S., Junghagen, S. and Harris, U. (2003), Strategic Affiliate Marketing, Edward Elgar Publishing, Cheltenham.

Gozzi, E. and Frountzos, A. (2014), Årlig Genomgång av Svensk Fotbollsekonomi: Rätt Skor för Fotbollen, Deloitte Sports Business Group, Stockholm.

Grohs, R., Wagner, U. and Vsetecka, S. (2004), “Assessing the effectiveness of sport sponsorships - an empirical examination", Schmalenbach Business Review, Vol. 56 No. 2, pp. 119-138.

Henseler, J., Wilson, B. and Westberg, K. (2011), "Managers' perceptions of the impact of sport sponsorship on brand equity: which aspects of the sponsorship matter most?", Sport Marketing Quarterly, Vol. 20 No. 1, pp. 7-21.

Hunt, K.A., Bristol, T. and Bashaw, R.E. (1999), “A conceptual approach to classifying sports fans”, Iournal of Services Marketing, Vol. 13 No. 6, pp. 439-452.

Jiffer, M. and Roos, M. (1999), Sponsorship - A Way of Communicating, Ekerlids förlag, Stockholm. 
Jones, D. (2014), “All to play for: Football Money League”, Sports Business Group at Deloitte, Deloitte, Manchester.

Jones, D. (2017), "Planet football: Football Money League”, Sports Business Group at Deloitte, Deloitte, Manchester.

Keller, K.L. (2003), Building, Measuring and Managing Brand Equity, Prentice Hall, Upper Saddle River, NJ.

KPMG (2017), "The European Champions Report. KPMG Tanácsadó Kft, Budapest, Hungary, available at: www.footballbenchmark.com/documents/files/public/The_European_ ChampCham_Report_2017.pdf (accessed 10 January 2018).

Kumar, V., Aksoy, L., Donkers, B., Venkatesan, R., Wiesel, T. and Tillmanns, S. (2010), "Undervalued or overvalued customers: capturing total customer engagement value”, Journal of Service Research, Vol. 13 No. 3, pp. 297-310.

Lacey, R. and Close, A.G. (2013), "How fit connects service brand sponsors with consumers' passions for sponsored events", International Iournal of Sports Marketing \& Sponsorship, Vol. 14 No. 3, pp. 212-228.

Louro, M.J. and Cunha, P.V. (2001), "Brand management paradigms", Lournal of Marketing Management, Vol. 17 Nos 7/8, pp. 849-875.

Malmö FF (2017), “Annual Report 2016”, available at: www.mff.se/ /media/MFF_2013/ Medlem/Arsmote_2017/2017-02-17 MFF_Årsredovisning_2016_.ashx?la=sv-SE (accessed 10 January 2018).

Masterman, G. (2007), Sponsorship - for a Return on an Investment, Elsevier, Amsterdam.

Mehus, I. (2010), "The diffused audience of football", Continuum: Iournal of Media \& Cultural Studies, Vol. 24 No. 6, pp. 897-903.

Mikhailitchenko, A.G., Tootelian, D.H. and Mikhailitchenko, G.N. (2012), "Exploring saturation levels for sponsorship logos on professional sports shirts: a cross-cultural study", International Iournal of Sports Marketing \& Sponsorship, Vol. 13 No. 4, pp. 267-281.

Morgan, A., Adair, D., Taylor, T. and Hermens, A. (2014), "Sport sponsorship alliances: relationship management for shared value", Sports, Business and Management: An International Journal, Vol. 4 No. 4, pp. 270-283.

Mullin, B., Hardy, S. and Sutton, W. (2014), Sport Marketing, 4th ed., Human Kinetics, Leeds.

Nufer, G. and Bühler, A. (2010), "Establishing and maintaining win-win relationships in the sports sponsorship business", Journal of Sponsorship, Vol. 3 No. 2, pp. 157-168.

O’Keeffe, M. and Zawadzka, J. (2011), "Does passion for a team translate into sales for a sponsor? The Irish case", Journal of Sponsorship, Vol. 4 No. 2, pp. 190-196.

Otker, T. (1988), "Exploitation: the key to sponsorship success", European Research, Vol. 16 No. 2, pp. $77-86$.

Ray, M.L. (1973), “Communication and the hierarchy of effects”, in Clarke, P. (Ed.), New Models for Mass Communication Research, Sage, Beverly Hills, CA, pp. 147-176.

Reichertz, J. (2009), "Abduction: the logic of discovery of grounded theory", Forum Qualitative Sozialforschung/Forum: Qualitative Social Research, Vol. 11 No. 1, available at: http://www. qualitative-research.net/index.php/fqs/article/view/1412/2902

Reysen, S., Snider, J.S. and Branscombe, N.R. (2012), "Corporate renaming of stadiums, team identification, and threat to distinctiveness", Journal of Sport Management, Vol. 26 No. 4, pp. 350-357.

Sahlström, K. (2017), “Analys av allsvenska klubbarnas ekonomi 2016”, Svenska Fotbollförbundet (in Swedish), Stockholm.

Sandvoss, C. (2003), A Game of Two Halves - Football, Television and Globalization, Routledge, London.

Saunders, M., Lewis, P. and Thornhill, A. (2016), Research Methods for Business Students, 7th ed., Pearson Education, Harlow. 
SBM

8,4

Shaw, R.N. and McDonald, H. (2006), "Season-ticket holder satisfaction and sponsor-related behaviour: evidence of a positive relationship", International Journal of Sports Marketing \& Sponsorship, Vol. 7 No. 4, pp. 318-325.

Smith, G. (2004), "Brand image transfer through sponsorship: a consumer learning perspective", Journal of Marketing Management, Vol. 20 Nos 3/4, pp. 457-474.

Spielmann, N. and Richard, M.-O. (2013), "How captive is your audience? Defining overall advertising involvement", Lournal of Business Research, Vol. 66 No. 4, pp. 499-505.

Tapp, A. and Clowes, J. (2002), "From 'carefree casuals' to 'professional wanderers': segmentation possibilities for football supporters”, European Journal of Marketing, Vol. 36 Nos 11/12, pp. 1248-1269.

Thompson, P. and Speed, R. (2007), "A typology of sponsorship activity”, in Parent, M.M. and Slack, T. (Eds), International Perspectives on the Management of Sport, Elsevier Academic Press, Burlington, MA, pp. 247-267.

Tsiotsou, R. (2013), "Investigating the role of enduring and situational involvement with the program context on advertising effectiveness", Journal of Marketing Communications, Vol. 19 No. 2, pp. 114-135.

Urriolagoitia, L. and Planellas, M. (2007), "Sponsorship relationships as strategic alliances: a life cycle model approach”, Business Horizons, Vol. 50 No. 2, pp. 157-166.

Vale, J., Serra, E., Vale, V. and Vieira, J. (2009), "The impact of sponsorship on a football team's brand equity”, Journal of Sponsorship, Vol. 2 No. 3, pp. 267-280.

Vance, L., Raciti, M.M. and Lawley, M. (2016), "Beyond brand exposure: measuring the sponsorship halo effect", Measuring Business Excellence, Vol. 20 No. 3, pp. 1-14.

van Uden, J. (2005), "Transforming a football club into a 'total experience' entertainment company: implications for management", Managing Leisure, Vol. 10 No. 3, pp. 184-198.

Vaughn, R. (1980), “How advertising works: a planning model”, Journal of Advertising Research, Vol. 20 No. 5, pp. 27-33.

Verhoef, P.C., Reinartz, W.J. and Krafft, M. (2010), "Customer engagement as a new perspective in customer management”, Lournal of Service Research, Vol. 13 No. 3, pp. 247-252.

Wagner, U., Persson, H.T.R. and Overbye, M. (2017), "Sponsor networks and business relations orchestrated by team sports clubs", Sport. Business and Management: An International Iournal, Vol. 7 No. 4, pp. 426-443.

Walraven, M., Koning, R.H. and van Bottenburg, M. (2012), "The effects of sports sponsorship: a review and research agenda", The Marketing Review, Vol. 12 No. 1, pp. 17-38.

Wang, A. (2009), "Cross-channel integration of advertising: does personal involvement matter?", Management Research News, Vol. 32 No. 9, pp. 858-873.

Woisetschläger, D.M., Backhaus, C. and Cornwell, T.B. (2017), "Inferring corporate motives: how deal characteristics shape sponsorship perceptions", Journal of Marketing, Vol. 81 No. 5, pp. 121-141.

Yin, R.K. (2014), Case Study Research: Design and Methods, 5th ed., Sage Publications, Los Angeles, CA.

Zaharia, N., Biscaia, R., Gray, D. and Stotlar, D. (2016), "No more 'good' intentions: purchase behaviors in sponsorship”, Lournal of Sport Management, Vol. 30 No. 2, pp. 162-175.

\section{Appendix. Interview guide}

\section{Introduce the respondent to the context of the study}

"Thank you for making yourself available for this interview. The aim of the study is to explore the motives for sponsors to engage in a sponsorship agreement with Malmö FF, and to explore how the club meets these expectations. I have identified a number of concepts that I would like to discuss with you. Please feel free to elaborate in whatever way you choose yourself. I might follow up with further questions on the topic, all depending on how you relate to the questions. I would finally like to audio-record the interview if you accept it". 
The objective of the non-structured interviews is twofold

(1) interviews with decision makers for the sponsor companies aimed to explore the motives for a sponsor to engage in a sponsorship agreement with the case club; and

(2) interviews with decision makers in the case club aimed to explore in what way they perceive that they create value.

The interview themes identified in the literature are the following

(1) Interviews with sponsors:

- the extent to which sponsors value the exposure potential in the sponsorship agreement;

- the extent to which sponsors perceive activation and leverage as valuable in the sponsorship agreement;

- the extent to which sponsors see a strategic fit with the sponsee;

- the extent to which sponsors benefit from long-term relationships resulting from the sponsorship agreement; and

- the extent to which sponsors perceive the potential increase in transactions with customers as a result of the sponsorship agreement.

(2) Interviews with the club:

- the perceived value the club can offer sponsors by means of exposure;

- in what way the club offers means for activation and leverage;

- the importance of a strategic fit between sponsors and the club - from the club perspective; and

- the extent to which long-term relationships with the sponsor are important to the club.

Each of the interview themes is introduced by means of a question. If needed, explain what is meant by, e.g. activation, leverage or strategic fit. Depending on the response, ask probing questions, until a perceived saturation is reached.

\section{Additional notes}

- how the interviewee appeared to me;

- the perceived motivation and disposition for the interviewee to participate;

- $\quad$ specific gestures, eye contact, body language;

- potential difficulties during the interview; and

- the main points made by the interviewee - also expressed to the interviewee after the formal interview for confirmation.

\section{Corresponding author}

Sven Junghagen can be contacted at: sven.junghagen@cbs.dk

For instructions on how to order reprints of this article, please visit our website: 